\title{
A Review : Degradasi Elektrokimia Zat Pewarna Golongan Azo (Azo Dyes)
}

\author{
Lily Arlianti ${ }^{1)}$ dan Ismi Nurlatifah ${ }^{2)}$ \\ *Jurusan Teknik Kimia, Fakultas Teknik, Universitas Islam Syekh Yusuf, Jl. Mulana Yusuf No.10 \\ Tangerang Banten 15118, Indonesia \\ 1) larlianti@unis.ac.id \\ 2) isminurlatifah@unis.ac.id
}

\begin{abstract}
Abstrak. Berkembangnya berbagai bidang industri yang menggunakan pewarna sintetis di dunia berimbas pada meningkatnya pencemaran lingkungan air di sekitar lingkungan industry tersebut. Pencemaran lingkungan air oleh limbah zat warna ini berbahaya untuk kesehatan manusia maupun biota air di tempat lingkungan tercemar. Penanggulangan limbah cair zat warna sintetis ini sudah banyak dikembangkan berbagai metode seperti fotolisis, biodegradasi, elektrokimia dan sebagainya. Degradasi elektrokimia sudah berkembang saat ini dengan elektroda-elektroda baru terhadap berbagai zat warna sintetis. Zat warna sintetis yang paling luas penggunaannya adalah zat warna azo yang memiliki spesifikasi ikatan $\mathrm{N}=\mathrm{N}$. Artikel ini menampilkan berbagai riset yang dilakukan oleh peneliti-peneliti yang mengembangkan degradasi elektrokimia terhadap berbagai zat warna sintetis azo (azo dyes). Metode ini memberikan hasil yang signifikan terhadap dekolorisasi zat warna dan COD removal yang sangat bagus diberbagai hasil riset. Sehingga degradasi elektrokimia merupaka metode yang menjanjikan dimasa depan untuk penanggulangan limbah zat warna yang ramah lingkungan karena penggunaan bahan kimia yang sedikit.
\end{abstract}

Kata kunci: Azo Dyes, degradasi elektrokimia, pencemaran lingkungan

Abstract. [A Review: Electrochemical Degradations of Azo Dyes] The development of various industrial fields that use synthetic dyes in the world impact on increasing pollution of the water environment around the industry environment. Water pollution by dyestuff waste is harmful to human health and water biota in polluted environment. Countermeasures of synthetic dyestuff liquid waste has been developed many methods such as photolysis, biodegradation, electrochemistry and so on. Electrochemical degradation has grown today with new electrodes against various synthetic dyes. The most widely used synthetic dye is the azo dye having the $\mathrm{N}=\mathrm{N}$ bond specification. This article presents various studies conducted by researchers who developed electrochemical degradation against various azo dyes (azo dyes) synthetic dyes. This method provides significant results on the decolorization of dye and COD removal is very good in various research results. So electrochemical degradation is a promising method in the future for environmentally friendly dyestuff prevention because of the use of few chemicals.

Keywords: Azo Dyes, Electrochemical Degradations, environmental pollution

\section{Pendahuluan}

Berkembangnya industri ang menggunakan pewarna seperti tekstil, penyamakan kulit, kertas dan pangan ini berimbas pada semakin banyaknya penggunaan zat warna organik sintetis. Berbagai pewarna sintetis yang sudah digunakan seperti dari golongan antrakuinon, arylmetan, akridin dan azo. Pewarna golongan Azo saat ini merupakan pewarna yang paling luas digunakan diberbagai industri.

Senyawa golongan azo memiliki karakteristik ikatan $(-\mathrm{N}=\mathrm{N}-)$ yang disebut gugus azo. Berbagai jenis senyawa azo digunakan secara luas sebagai pewarna dan indikator ( Yuliana,dkk.,2015). Senyawa azo disintesis melalui reaksi diazotisasi untuk menghasilkan garam diazonium dilanjutkan dengan reaksi kopling azo. Rekasi kopling azo merupakan reaksi subtitusi elektrofilik aromatik pada cincin benzene aktif sebagai nukleofil dan ujung garam diazonium sebagai elektrofil (Bruice, 2004).

Salah satu contoh sintetis zat pewarna azo terlihat pada Gambar 1. 


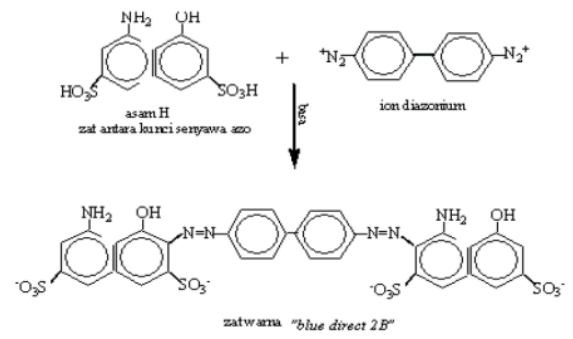

Gambar 1. Sintesis zat warna 'Blue Direct 2B'(Maria Christina, dkk., 2007)

Berbagai zat warna sintesis golongan azo digunakan secara luas di dunia diantaranya kuning metanil, metil jingga, Cybacron Navy WB, Acid Blue dan sebagainya. Diperkirakan saat ini pemakaian azo dyes di dunia sekitar 50$70 \%$ dari total pemakaian zat warna industri (Valica \& Hostin, 2016). Pemakaian zat warna sintetis ini di berbagai industri secara luas memberikan efek pada pencemaran lingkungan air di sekitar pabrik- pabrik pengguna. Pencemaran air ini menjadi masalah berat jika sudah melwati ambang batas parameterparameter air yang ditentukan oleh pemerintah Indonesia. Limbah cair di atas ambang batas dari industri ini akan mempengaruhi kesehatan penduduk yang bermukim disekitar pabrik. Untuk itu perlu dikembangkan metode-metode penanggulangan limbah yang cepat dan efisien. Salah satunya adalah pengolahan limbah dengan metode elektrokimia.

Prinsip dasar metode elektrokimia adalah oksidasi polutan pada permukaan elektroda dan pada proses ini tidak ada oemakaian reagen kimia (Valica \& Hostin, 2016). Berikut reaksi yang terjadi pada peristiwa oksidasi elektrokimia menurut Valica \& Hostin (2016).

$$
\begin{gathered}
2 \mathrm{H}_{2} \mathrm{O}+2 \mathrm{e}^{-} \rightarrow 2 \mathrm{OH}^{-}+\mathrm{H}_{2} \\
2 \mathrm{H}_{2} \mathrm{O}+\mathrm{O}_{2}+4 \mathrm{e}^{-} \rightarrow 4 \mathrm{OH}^{-} \\
3 \mathrm{H}_{2} \mathrm{O} \rightarrow \mathrm{O}_{3}+6 \mathrm{e}^{-}+6 \mathrm{H}^{+} \\
\mathrm{O}_{2}+2 \mathrm{H}_{2} \mathrm{O}+2 \mathrm{e}^{-} \rightarrow \mathrm{H}_{2} \mathrm{O}_{2}+2 \mathrm{OH}^{-} \\
2 \mathrm{Cl}^{-} \rightarrow \mathrm{Cl}_{2}+2 \mathrm{e}^{-} \\
\mathrm{Cl}_{2}+\mathrm{H}_{2} \mathrm{O} \rightarrow \mathrm{H}^{+}+\mathrm{Cl}^{-}+\mathrm{HOCl} \\
\mathrm{HOCl} \rightarrow \mathrm{H}^{+}+\mathrm{OCl}^{-}
\end{gathered}
$$

Sel elektrokimia secara sederhana dapat dilihat pada Gambar 2 berikut ini.

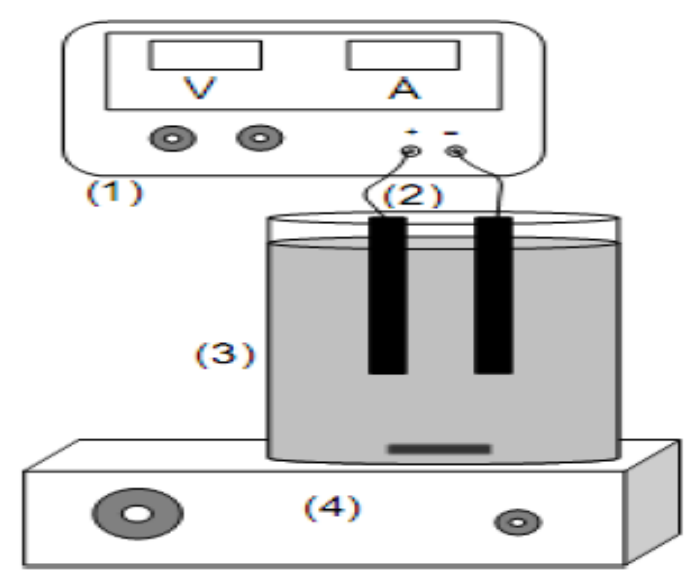

Gambar 2. Skema rangkaian sel elektrokimia (!) Sumber arus (2) sepasang elektroda (\#) larutan elektrolitik (4) pengaduk magnetic (Lily Arlianti dkk, 2014).

\section{Metodologi dan Pembahasan \\ 2.1. Degradadasi Methyl Orange (MO)}

Valica \& Hostin (2016) telah melakukan degradasi elektrokimia pada limbah cair yang terkontaminasi MO menggunakan elektroda grafit.<smiles>CN(C)c1ccc(/N=N/c2ccc(S(=O)(=O)O[NH3+])cc2)cc1</smiles>

Gambar 4. Struktur Methyl Orange

Peneliti melakukan degradasi dengan variasi arus listrik dan larutan leketrolit yakni $\mathrm{NaCl}$. Didapatkan hasil bahwa persentase degradasi MO tertinggi adalah 91,0\% dengan arus 3,032 $\mathrm{mA} / \mathrm{cm}^{2}$ dan konsentrasi $\mathrm{NaCl} 4 \mathrm{~g} / \mathrm{dm}^{3}$ dalam waktu 35 menit.

\subsection{Degradasi Pewarna Azo RR120 (Red HE3B)}

Pewarna azo RR120 di degradasi menggunakan elektroda grafit sebagai anoda dan stainless steel sebagai katoda. Riset dilakukan dengan variasi konsentrasi zat warna 100-500 $\mathrm{mg} / \mathrm{L}$, konsentrasi larutan elektrolit $\mathrm{NaCl} 2500$ $12,500 \mathrm{mg} / \mathrm{L}$, variasi waktu elektrolisi 7,5 - 37,5 menit dan arus listrik 0,06 sampai 0,3 A. Dua batch reaktor digunakan dengan separator selulosa.

Dari hasil riset didapatkan kondisi optomin degradasi terhadap zat warna RR120 adalah konsentrasi RR120 $200 \mathrm{mg} / \mathrm{L}$, arus 0,12 A, konsentrasi $\mathrm{NaCl} 7914,29 \mathrm{mg} / \mathrm{L}$ dengan waktu elektrolisis selama 30 menit RR120 terdegradasi sebesar 99,44\% via elektrooksidasi 
dan $32,38 \%$ via elektro reduksi (Najafpoor dkk, 2017).

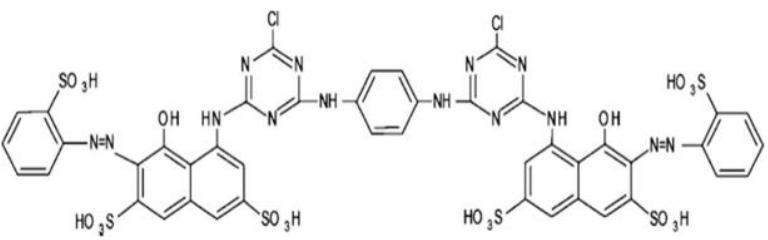

Gambar 4. Struktur molekul RR120

\subsection{Degradasi pewarna Cybacron Navy WB}

Kariyajjanavar dkk (2010) telah melakukan degradasi secara elektrokimia terhadap zat warna azo Cybacron Navy WB menggunakan elektroda karbon grafit dengan proses voltametri siklik didalam asam sulfat dengan potensial listrik $+700 \mathrm{mV}$ sampai $-450 \mathrm{mV}$. Kurva voltametri dari CNWB memeperlihatkan puncak katodik pada $+50 \mathrm{mV},-155 \mathrm{mV}$ dan $-317 \mathrm{mV}$ dan puncak anodic pada $+382 \mathrm{mV}$ dan $+547 \mathrm{mV}$ masing-masingnya. Efisiensi dekolorisasi dianalisis menggunakan UV-Vis serta zat warna dianalisis secara LC-MS pada sebelum dan sesudah proses elektrokimia dan sudah terkonfirmasi bahwa gugus azo dan cincin aromatic sudah hilang.

Efek $\mathrm{pH}$ dan larutan elektrolit juga dipelajari dengan hasil yang didapat adalah nilai maksimum COD removal hampir 100\% dengan konsentrasi $\mathrm{NaCl} 5 \mathrm{~g} / \mathrm{L}$.

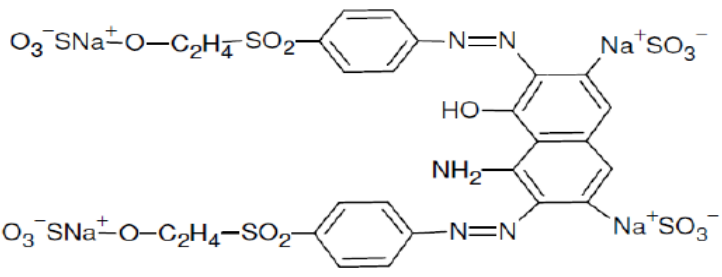

Gambar 5. Struktur molekul CNWB

\subsection{Degradasi Acid Blue 113 (AB113)}

Degradasi AB113 telah dilakukan secara oksidasi elektrokimia menggunakan elektroda $\mathrm{Ti} / \mathrm{Pt}$, timbal dioksida $\left(\mathrm{Pb} / \mathrm{PbO}_{2}\right)$ dan $\mathrm{Ti} / \mathrm{TiO}_{2^{-}}$ nanotube $/ \mathrm{PbO}_{2}$ ) sebagai anoda-anoda. Sel elektrolisis berjalan di dalam $1 \mathrm{~L}$ larutan yang berisi $250 \mathrm{mg} / \mathrm{dm}^{3}$ pewarna AB113 menggunakan $\mathrm{Na}_{2} \mathrm{SO}_{4}$ sebagai larutan elektrolit dengan arus 20, 40 dan $60 \mathrm{~mA} / \mathrm{cm}$. Proses elektrolisis dimonitor menggunakan spektrometri UV-Vis dan COD dimana hasil menunjukkan $\mathrm{AB} 113$ sukses terdegradasi.
Berikut tabel hasil degradasi menggunakan anoda-anoda yang berbeda.

Tabel 1. COD removal dengan 3 anoda yang berbeda

\begin{tabular}{llllll}
\hline Experimental conditions & & $\mathrm{Q}\left(\mathrm{Ahdm}^{-3}\right)$ & $\mathrm{CR}(\%)$ & $\mathrm{COD}($ \%) & $\mathrm{EC}\left(\mathrm{kWhm}^{-3}\right)$ \\
\hline Anode & $j\left(\mathrm{mAcm}^{-2}\right)$ & & & & \\
\hline Ti/pt & 20 & 7.62 & 93 & 13.7 & 48.5 \\
& 40 & 7.62 & 66 & 9.5 & 73.2 \\
& 60 & 7.62 & 51 & 7.2 & 57.7 \\
$\mathrm{~Pb} / \mathrm{Pb} 0_{2}$ & 20 & 6.35 & 89 & 74.3 & 56.3 \\
& 40 & 7.62 & 88 & 62.1 & 87.1 \\
& 60 & 7.62 & 88 & 59.8 & 92.5 \\
Ti/TiO2. nanotubes/Pb0 2 & 20 & 7.62 & 98 & 92.5 & 39.2 \\
& 40 & 7.62 & 98 & 89.8 & 58.2 \\
& 60 & 7.62 & 98 & 88.4 & 70.3 \\
\hline
\end{tabular}

Terlihat dari tabel COD removal yan tertinggi adalah menggunakan anoda Ti/TiO2nanotube/ $\mathrm{PbO} 2$ yakni $88,4 \%$ sampai $92,5 \%$ (de Maura dkk, 2016).

\subsection{Degradasi pewarna Reactive Blue 4 (RB- \\ 4) dan Reactive Orange (RO-16)}

Da Silva dkk (2011) telah melakukan degradasi secara oksidasi elektrokimia terhadap pewarna RB-4 dan RO-16. Mereka melakukan eletrolisis dengan dan tanpa media elektrolit dan terlihat hasil menggunakan larutan elektrolit klorida memberikan efisiensi degradasi yang lebih tinggi yakni sampai $80 \%$ COD removal. Elektroda logam oksida yang mengandung $\mathrm{RuO}_{2}$ memperlihatkan kinerja yang baik untuk oksidasi anodik di dalam media klorida sehingga disimpulkan bahwa $\mathrm{Ti} /\left(\mathrm{RuO}_{2}\right)_{0.70}\left(\mathrm{Ta}_{2} \mathrm{O}_{5}\right)_{0.30}$ merupakan komposisi yang paling ramah lingkungan.

A<smiles>Nc1c(O)cc2c(c1NCc1cccc(O)c1)C(=O)c1ccccc1C2=O</smiles>

B

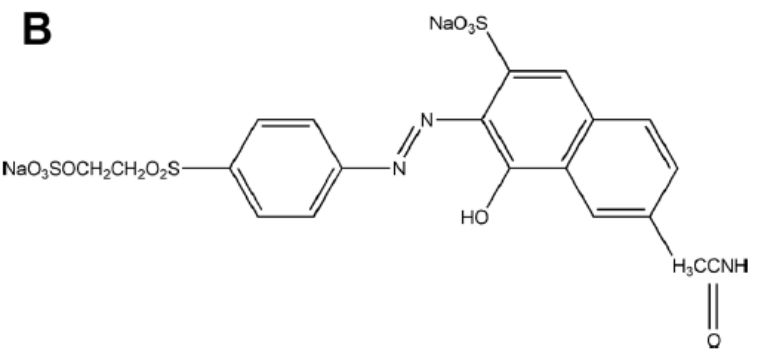

Gambar 6. Struktur molekul RB-4 dan RO16

\subsection{Degradasi Pewarna Reactive Yellow 160 (RY160)}

Tiga elektroda termodifikasi $\left(\mathrm{C} / \mathrm{PbO}_{2}\right.$, $\mathrm{Pb}+\mathrm{Sn} / \mathrm{PbO}_{2}+\mathrm{SnO}_{2}$ dan $\mathrm{Pb} / \mathrm{PbO}_{2}$ yang 
dipersiapkan dengan cara elektrodeposisi digunakan sebagai anoda untuk mendegradasi RY160 secara elektrokimia. Elektrolisis dilakukan pada kondisi yang berbeda seperti arus listrik, suhu, pH, konsentrasi RY160, larutan elektrolit dan waktu elektrolisis. Didapatkan hasil RY160 terdegradasi sempurna masing-masing sebesar 97,9\%, 96,65\% dan 93,35\% menggunakan elektroda $\mathrm{C} / \mathrm{PbO}_{2}$, $\mathrm{Pb}+\mathrm{Sn} / \mathrm{PbO}_{2}+\mathrm{SnO}_{2}$, and $\mathrm{Pb} / \mathrm{PbO}_{2}$ dengan $\mathrm{NaCl}$ $(4 \mathrm{~g} / \mathrm{L})$ setelah 15 menit elektrolisis pada $\mathrm{pH}$ 7,3 (Mohamed Gaber dkk, 2013)

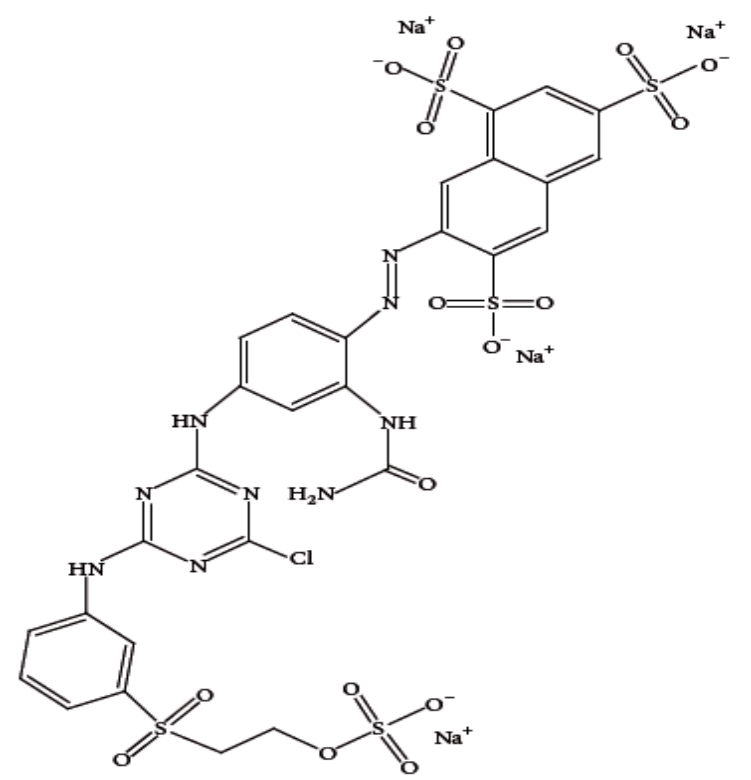

Gambar 7. Struktur molekul RY160

\subsection{Degradasi Pewarna Remazol Black B (CI Reactive Black 5)}

Telah dilakukan degradasi elektrokimia terhadap pewarna hidrolisis Remazol Black B dengan tiga tipe reaktor yang berbeda yaitu batch, resirkulasi batch dan single pass system. Efek arus listrik, konsentrasi elektrolit dan waktu elektrolisis dan konsumsi energi dievaluasi. Hasil riset memperlihatkan reaktor batch resirkulasi memiliki hasil yang paling bagus disbanding reaktor lain. Kondisi optimum didapatkan pada arus $2,5 \mathrm{~mA} / \mathrm{dm}^{2}$, lama elektrolisis 6 jam dan konsentrasi elektrolit 3g/L. Color removal sempurna terjadi setelah 3 jam elektrolisis dengan berbagai kombinasi parameter (P.A.Soloman dkk, 2009).

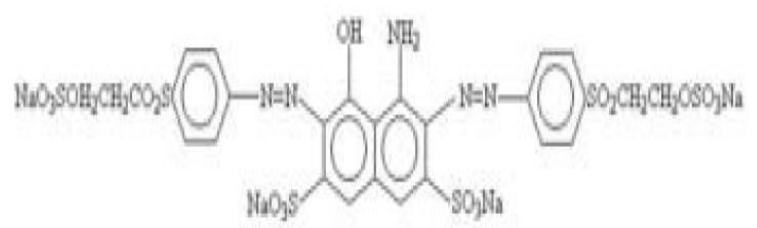

Gambar 8. Struktur molekul CI Reactive Black 5

\subsection{Degradasi Kuning Metanil}

Degradasi elektrokimia terhadap zat warna azo kuning metanil sudah dilakukan menggunakan elektroda pasta karbon nanopori dan perak. Pasta karbon dibuat dari campuran bubuk karbon nanopore dengan paraffin yang dikemas di dalam tip micropipet yang disematkan pada kawat tembaga. Bentuk elektroda pasta karbon dapat dilihat pada Gambar 9 dibawah ini.

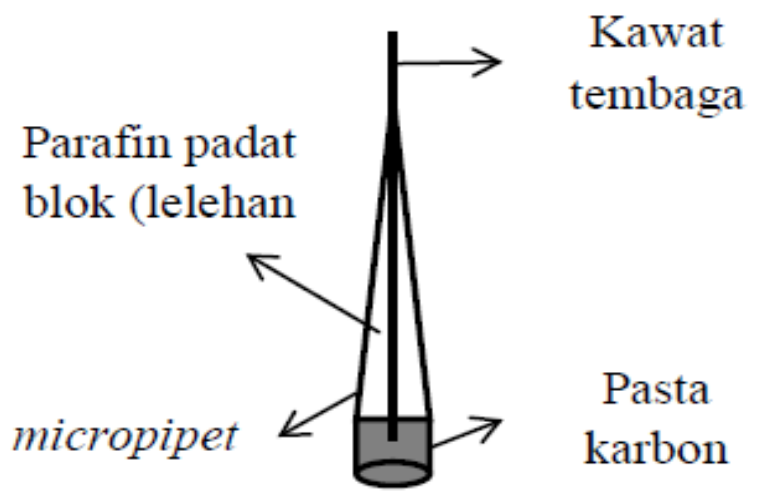

Gambar 9. Elektroda pasta karbon nanopori

Optimasi potensial degradasi yang dilakukan pada larutan kuning metanil $10 \mathrm{mg} / \mathrm{L}$ dengan variasi potensial dari 3 sampai 21 Volt dengan larutan elektrolit pendukung $\mathrm{NaCl} 0,1 \mathrm{M}$ dilakukan selama 10 menit dan diperoleh potensial yang memberikan persentase degradasi optimum adalah $12 \mathrm{~V}$. Pemilihan larutan elektrolit pendukung diperoleh hasil $\mathrm{NaCl} 0,1 \mathrm{M}$ yang terbaik dengan derajat keasaman larutan kuning metanil optimum pada $\mathrm{pH} 1$ sedangkan waktu degradasi optimum pada menit ke 15 dan maksimum pada menit ke 40 yaitu 99,47\%.

Pengaruh $\mathrm{pH}$ terhadap degrdasi kuning metanil memeperlihat kondisi $\mathrm{pH} 1$ sebagai optimum ini disebabkan karena kondisi asam mengakibatkan terjadinya peristiwa protonasi pada ikatan $\mathrm{N}=\mathrm{N}$. Grafik pengaruh $\mathrm{pH}$ terhadap degradasi kunig metanil dapat dilihat pada Gambar 10. 


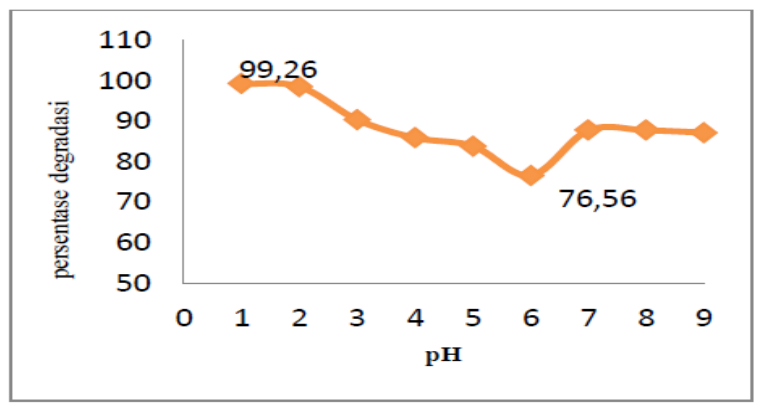

Gambar 10. Pengarih $\mathrm{pH}$ terhadap degradasi kuning metanil

Dilakukan juga evaluasi terhadap degradasi kuning metanil dengan pengaturan $\mathrm{pH}$ optimum yaitu 1 dan tanpa pengaturan $\mathrm{pH}$, hasilnya dapat dilihat pada grafik di Gambar 11.

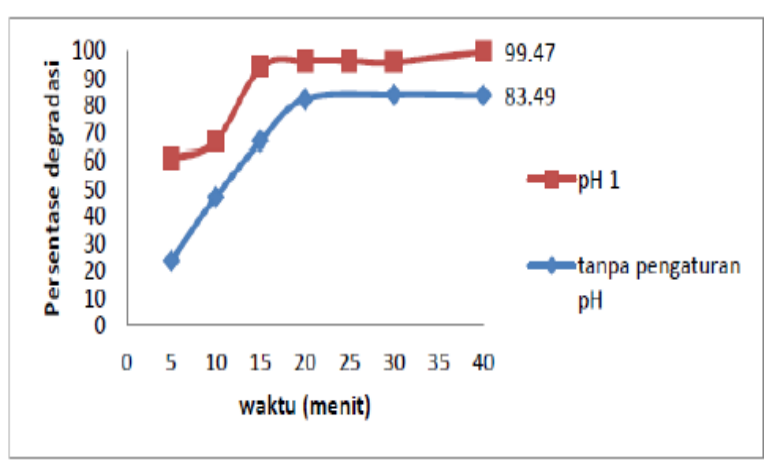

Gambar 11. Waktu degradasi dengan pengaturan $\mathrm{pH}$ dan tanpa pengaturan $\mathrm{pH}$

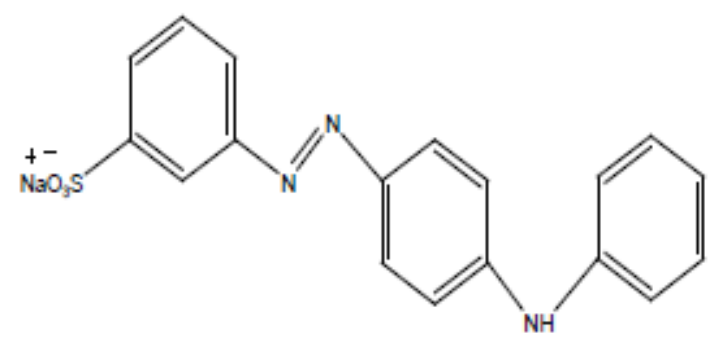

Gambar 12. Struktur molekul kuning metanil

Analisis COD terhadap larutan kuning metanil $10 \mathrm{ppm}$ dan $50 \mathrm{ppm}$ sebelum dan sesudah degradasi didapatkan hasil seperti terlihat pada Tabel 2.

Tabel 2. Nilai COD sebelum dan sesudah degradasi serta pada blanko $\mathrm{NaCl} 0,1 \mathrm{M}$

\begin{tabular}{|c|c|c|c|} 
Larutan & $\begin{array}{c}\text { COD }(\mathbf{m g} / \mathbf{L}) \\
\text { sebelum } \\
\text { degradasi }\end{array}$ & $\begin{array}{c}\text { COD }(\mathbf{m g} / \mathbf{L}) \\
\text { Sesudah } \\
\text { degradasi }\end{array}$ & $\begin{array}{c}\text { COD } \\
\text { removal } \\
(\%)\end{array}$ \\
\hline $\begin{array}{c}\text { Kuning metanil 10 } \\
\text { ppm }\end{array}$ & 166,550 & 41,608 & $-75,02$ \\
\hline $\begin{array}{c}\text { Kuning metanil 50 } \\
\text { ppm }\end{array}$ & 324,240 & 32,112 & $-90,10$ \\
\hline $\mathrm{NaCl} \mathrm{0,1} \mathrm{M}$ & 30,100 & 62,170 & $+106,54$ \\
\hline
\end{tabular}

Turunnya nilai COD yang signifikan sampai $90,10 \%$ pada larutan kuning metanil $50 \mathrm{mg} / \mathrm{L}$. Pada konsentrasi $10 \mathrm{mg} / \mathrm{L}$ penurunannya lebih kecil, hal ini disebabkan sisa larutan elektrolit $\mathrm{NaCl}$ sebagai elektrolit pendukung yang mengganggu analisis COD karena terbentuknya HClO. Namun masih jauh dibawah ambang batas yang diijinkan pemerintah yaitu $150 \mathrm{mg} / \mathrm{L}$. Sedangkan COD untuk blanko yaitu $\mathrm{NaCl} 0,1 \mathrm{M}$ didapatkan nilai yang lebih tinggi pada larutan sesudah degradasi karena terbentuknya $\mathrm{HClO}$ yang banyak dan tidak terpakai untuk mendegradasi (Lily Arlianti dkk, 2014).

\subsection{Degradasi Pewarna Reactive Green 19 (RG19)}

Oksidasi anodic menggunakan elektroda Boron-doped Diamond (BDD) dengan kehadiran klorida untuk mendegradasi RG19 telah dilakukan oleh Antonio Zuorro dkk (2014). Hasil memperlihatkan bahwa elektrolisis dibawah kondisi galvanostatic dan reaktor bebas membrane terjadi reaksi yang dimediasi oleh radikal hidroksil dan klorin aktif. Suasana asam meningkatkan konsentrasi klorin dan waktu pengadukan.

Tabel 3. Koefisien regresi dari power-law model untuk variable respon $\bar{\imath}_{50}$ dan $\bar{l}_{99}$ dengan standar error (SE), t-statistik (t), p-value (p)

\begin{tabular}{cllrrrr}
\hline Time response Coefficient & Associated variable & Value & SE & $t$ & $p$ \\
\hline$T_{50}$ & $a_{1}$ & Dye concentration & 0.504 & 0.057 & 8.898 & $<0.0001$ \\
& $a_{2}$ & Chloride concentration & -0.772 & 0.050 & -15.445 & $<0.0001$ \\
& $a_{3}$ & Current density & -0.273 & 0.090 & -3.016 & 0.005 \\
& $a_{4}$ & Temperature & -0.735 & 0.090 & -8.222 & $<0.0001$ \\
& $a_{5}$ & pH & 0.345 & 0.106 & 3.257 & 0.003 \\
& $a_{6}$ & Stirring rate & -0.236 & 0.070 & -3.394 & 0.002 \\
\cline { 2 - 6 } & $a_{1}$ & Dye concentration & 0.672 & 0.066 & 10.131 & $<0.0001$ \\
$\tau_{99}$ & $a_{2}$ & Chloride concentration & -0.236 & 0.058 & -4.032 & $<0.0001$ \\
& $a_{3}$ & Current density & -0.341 & 0.106 & -3.213 & 0.003 \\
& $a_{4}$ & Temperature & -0.769 & 0.105 & -7.342 & $<0.0001$ \\
& $a_{5}$ & pH & 0.214 & 0.124 & 1.723 & 0.095 \\
& $a_{6}$ & Stirring rate & 0.672 & 0.066 & 10.131 & $<0.0001$ \\
\hline
\end{tabular}

2.10. Degradasi berbagai pewarna azo menggunakan elektroda platinum

Studi oksidasi elektrokimia terhadap berbagai pewarna tektil seperti Reactive 
Blue 52, Reactive Black 5, Reacktive Green 15 dan Reactive Yellow 125 menggunakan anoda platina. Elektrolisis dilakukan pada sel elektrokimia yang mengadung membrane sesuai membrane standar di industry. Membran memisahkan wilayah anoda dan katoda. Larutan elektrolit pendukung adalah Natrium sulfat $0,1 \mathrm{M}$. Potensial listrik yang digunakan adalah 6, 12, dan $24 \mathrm{~V}$ serta pengaruh membrane terhadap elektrolisis dievaluasi menggunakan pewarna model yaitu Reactive Blue 52. Derajat degradasi tertinggi terjadi pada potensial $12 \mathrm{~V}$ dan ini diambil sebagai kondisi optimum.

Nilai COD diambil setelah elektrolisis selama 60 menit dan didapatkan hasil pengukuran dibawah $<30 \mathrm{mg} / \mathrm{L}$ O2) kecuali Reactive Black 5 memiliki pengurangan nilai COD $57,95 \%$ dengan membrane dan 32,58\% tanpa membrane. Dekolorisasi terjadi sempurna setelah 10 menit sampai 60 menit elektrolisis untuk semua pewarna (Milica Jovic, 2012).

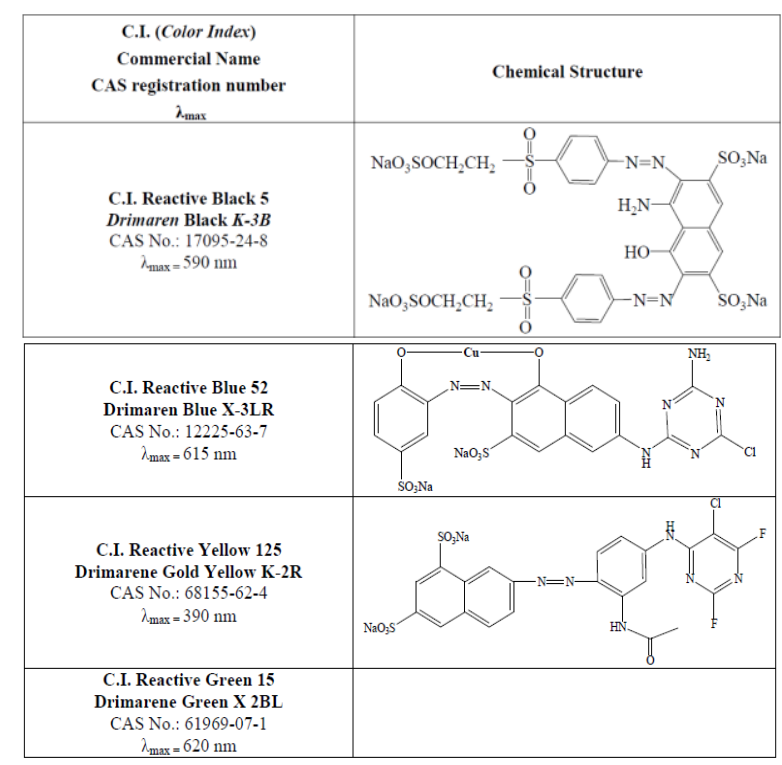

Gambar 13. Struktur molekul berbagai pewarna azo

\section{Kesimpulan}

Permasalahan lingkungan karena terjadinya pencemaran dari industri salah satunya karena penggunaan zat pewarna sintetis diantaranya dari golongan azo membutuhkan pengembangan berbagai metode penaggulangan limbah zat warna salah satunya elektrokimia. Metode elektrokimia ini merupakan metode yang menjanjikan di masa depan karena penggunaan bahan kimia yang sedikit dan dapat diarahkan untuk metode ramah lingkungan. Berbagai penelitian sudah dilakukan untuk mendegradasi at warna azo yang merupakan pewarna terluas pemakaiannya di dunia dan degradasi elektrokimia memberikan hasil yang signifikan yaitu dengan COD removal yang besar rata-rata diatas $80 \%$ bahkan banyak yang mendekati $100 \%$.

Untuk itu pengembangan metode elektrokimia untuk penanggulangan limbah zat warna sintetis sangat diperlukan baik pengembangan jenis dan tipe elektroda, tipe reaktor maupun jenis zat warnanya. Karena banyak sekali zat warna azo yang digunakan dengan merk dagang yang berbeda-beda. Indonesia sebagai negara berkembang dengan perkembangan industri yang meningkat dari tahun ke tahun sangat membutuhkan hal ini untuk memelihara dan pempertahankan lingkungan kita yang sehat, bersih dan aman untuk penduduk negara kita dan generasi yang akan datang.

\section{Daftar Pustaka}

Martin Valica dan Stanislav Hostin (2016), Electrochemical Treatment of Water Contaminated With Methyl Orange, Nova Biotechnologies et Chimica 15-1

Ali Asghar Najafpoor dkk (2017)

Decolorization of Synthetic Textile Wastewater Using Electrochemical Cell Devided by Cellulosic Separator, Journal of Environtment Health Science and Engineering, 15-11.

P. Kariyajjanavar dkk (2010), Electrochemical Degradation and Cyclic Voltammetric Studies of Textile Reactive Azo Dye Cibacron Navy WB, Portugaliae Electrochimica Acta, ISSN 1647-1571, 28(4), 265-277.

Dayanne Chianca de Moura dkk (2016),

Electrochemical Degradation of Acid Blue 113 Dye Using $\mathrm{TiO}_{2}$-nanotubes Decorated with $\mathrm{PbO}_{2}$ as anode, Environmental Nanotechnology, Monitoring \& Management 5, 13-20.

Rodrigo G. da Silva dkk, (2011)., Degradation 
of Reactive Dyes of Different DSA

Compositions, J. Braz, Chem.Soc,

Vol.22 No.1, 126-133.

Mohamed Gaber dkk (2013)., Electrochemical

Degradation of Reactive Yellow 160

Dye in Real Wastewater Using $\mathrm{C} / \mathrm{PbO}_{2^{-}}$, $\mathrm{Pb}+\mathrm{Sn} / \mathrm{PbO}_{2}+\mathrm{SnO}_{2^{-}}$, and $\mathrm{Pb} / \mathrm{PbO}_{2}$ Modified Electrodes, Hindawi Publishing Corporation, Journal of Chemistry Volume 2013.

Poppana Antony Soloman dkk (2009).,

Electrochemical Degradation of Rhemazol Black B Dye Effluent, Clean Journal, 37(11), 889-900.

Lily Arlianti dkk (2014)., Degradasi

Elektrokimia Kuning Metanil Menggunakan Elektroda Pasta Karbon Nanopori, Jurnal Matematika dan Ilmu Pengetahuan Alam, ISSN 0852-4556, Vol. 17 No.2.

Antonio Zuorro dkk (2014), Kinetic Modelling of Electrochemical Decolorization of Diazo Dyes on Boron-Doped Diamond Electrodes, Chemical Engineering Transactions, Vol.41, ISBN 978-8895608-32-7, ISSN 2283-9216.

Milica Jovic dkk (2013), Study of the

Electrochemical Oxidations of Reactive Textile Dyes Using Platinum Electrode, Int. J. Electrochem.Sci., 8, 168-183.

Maria Christina dkk (2007)., Studi Pendahuluan Mengenai Degradasi Zat Warna Azo (Metil Orange) Dalam Pelarut Air Menggunakan Mesin Berkas Elektron $350 \mathrm{keV} / 10 \mathrm{~mA}$, JFN, Vol.1, No.1, ISSN 1978-8738. 